\title{
Type 1 diabetes in an adolescent with social problems and mental disorders - case report
}

\author{
Cukrzyca typu 1 u nastolatki w obliczu problemów socjalnych i zaburzeń psychicznych
}

\author{
${ }^{1}$ Agnieszka Grobelczyk, ${ }^{1}$ Ewa Rusak, ${ }^{2}$ Sebastian Seget, ${ }^{3}$ Agata Chobot
}

${ }^{1}$ Pediatrics' Students Scientific Association, School of Medicine, University of Opole, Poland

${ }^{2}$ Department of Children's Diabetology, Medical University of Silesia, Poland

${ }^{3}$ Department of Pediatrics, Institute of Medical Sciences, University of Opole, Poland

\begin{abstract}
Discontinuation of type 1 diabetes (T1DM) treatment (interruption of insulin therapy) rapidly leads to diabetic ketoacidosis (DKA) which is a life-threatening condition. Our case report is intended to draw attention to persons with T1DM and significant social/ psychological problems. They typically, due to the lack of legal regulations, "fall out of the system", which should provide in such cases additional assistance in care conditioning proper treatment. Psychological an psychiatric disorders and/or social problems may interfere with self-control and diabetes treatment, making it difficult or even impossible. These patients represent a significant challenge for the diabetes team and require individualized management from the social care system. Patient safety-focused support from consulting physicians of other specialties is also essential. The case of our patient highlights the need for relevant legal and administrative regulations that would allow for quick, safe and adequate care.
\end{abstract}

Key words:

diabetes mellitus type 1, mental disorders, substance-related disorders.

\section{Streszczenie}

W cukrzycy typu 1 przerwanie leczenia (insulinoterapii) prowadzi do cukrzycowej kwasicy ketonowej (DKA), będącej stanem bezpośredniego zagrożenia życia. Celem przedstawionego opisu przypadku jest zwrócenie uwagi na sytuację pacjentów z cukrzycą typu 1 i istotnymi problemami socjalnymi/psychicznymi, którzy ze względu na brak odpowiednich uregulowań prawnych „wypadają z systemu", który mógłby zapewnić im odpowiednią opiekę warunkującą prawidłowe leczenie. Zaburzenia psychiczne i/lub problemy socjalne utrudniają lub uniemożliwiają prowadzenie samokontroli i leczenia. Pacjenci tacy stanowią istotne wyzwanie dla zespołu diabetologicznego i wymagają zindywidualizowanego postępowania ze strony systemu opieki społecznej. Niezbędne jest też skoncentrowane na bezpieczeństwie pacjenta wsparcie ze strony konsultujących lekarzy innych specjalności. Przypadek naszej pacjentki podkreśla potrzebę opracowania odpowiednich uregulowań prawnych i administracyjnych, które pozwoliłyby na szybkie, bezpieczne i adekwatne zaopiekowanie się takim pacjentem.

\section{Słowa kluczowe:}

cukrzyca typu 1 u dzieci, zaburzenia psychiatryczne, zaburzenia związane z substancjami psychoaktywnymi.

\section{Introduction}

Type 1 diabetes (T1D) is a condition in which insulin replacement therapy is required promptly after diagnosis. Stopping insulin treatment in T1D quickly leads to a life-threatening condition - diabetes ketoacidosis (DKA). Nevertheless, insulin overdosing is also dangerous and may be fatal.

Treatment of T1D depends greatly on patients' self-management, which is supported by the therapeutic team. Blood glucose monitoring and adjustment of insulin doses to meals and physical activity - insulin therapy - are crucial components of self-management. All these activities require patient's and/ or the caregivers' involvement and dedication. Hence, awareness and responsibility are vital for safe and successful diabetic therapy [1].

Family concerns (e.g. low parental involvement, conflicts, criticism, overprotection), economic and social problems (e.g. exclusion from a peer group, minority status), or mental disorders are related to worse glycaemic control, higher risk of acute and chronic complications [1, 2], and compound the patients' 
prognosis [1-3]. Despite the rising T1D incidence in Poland [4-6] no good systemic, administrative procedures and tools have been developed that would allow the provision of such patients with adequate care.

\section{Aim of the study}

We present the case of our patient to emphasise the problem of ensuring safe and adequate T1D therapy in people with significant social and/or mental problems.

\section{Case study}

Our patient was diagnosed with T1D at the age of 17 years (July 2019). At that time, she had lived in a correctional institution (Youth Educational Centre [YEC]) since January 2017 because of notorious home runaways, school absenteeism, and abuse of designer drugs. She was admitted to the regional diabetes centre with typical symptoms of hyperglycaemia, dehydration, and compensated metabolic acidosis.

She claimed to have problems sleeping. Traits of psychotropic drugs were found. Her general condition was average, she had trouble focusing. Physical examination revealed scars after self-inflicted forearm cutting injuries. Standard symptomatic treatment and insulin therapy were implemented according to the current recommendations of Diabetes Poland. Extended diagnostics showed hyperthyroidism. The consulting psychiatrist diagnosed behavioural and emotional disorders and polytoxicomania.

Within 7 months of the diagnosis she escaped several times from the YEC, home, or hospital and was 7 times hospitalized due to DKA (3 times in an Intensive Care Unit [ICU]). The descriptions of psychological consultations from that time include the following: occasional eye contact, maintained verbal-logical contact, unstable mood, occasional interruptions from prescribed pharmacotherapy (psychiatric treatment, insulin therapy, and treatment of hyperthyroidism), and regular glucose control.

In December 2019 she was again admitted to the diabetes centre in Katowice because of severe DKA. She ran away from the hospital before being transferred to the YEC. Police and other authorities were unsuccessful in finding her.

A few weeks later emergency services brought her in a critical state to one of the regional hospitals, from where she was transferred to the Paediatric Intensive Care Unit (PICU) in Opole. On admission she was unconscious (GCS: 6 points), with symptoms of hypovolaemic shock (hypotension, tachycardia, grey cold skin, delayed capillary return, body temperature $34^{\circ} \mathrm{C}$ ) and severe DKA (pH: 6.8, glycaemia > $1000 \mathrm{mg} \%$ ). As her state improved she patient was moved to the paediatric ward.

The consulting psychologist concluded that despite declaring life-threatening awareness, she neglected her treatment and showed self-destructive behaviour related to the lack of treatment and ostentatious consumption of excessive amounts of sugar. Taking all of the above into consideration, adequate self-management after discharge was doubtful with a high risk of neglecting insulin administration. Therefore, the patient was transferred to a psychiatric ward in another hospital. The attending psychiatrist from the psychiatric admission's chamber refused to admit her to hospital, taking into account her lack of consent for hospitalization (in spite of the consent of the minor's mother). She also denied a suicide attempt (the patient claimed that she unintentionally forgot to take her medication).

The patient was temporarily sent to the Police Emergency Youth Centre (PEYC) from where she was supposed to go back to the YEC, but the director raised significant concerns about the ability to ensure proper care, including supervision of diabetes self-control and the legal consequences (including death) related to possible discontinuation of treatment. The PEYC was not able to ensure supervision over T1DM treatment so after not more than a day the girl was re-admitted to the paediatric department - this time under 24-hour police supervision. Finally, after numerous interventions of the hospital, YEC, and PEYC, the court ordered an obligatory observation in the psychiatric ward (conscious multiple discontinuation of insulin therapy, resulting in severe DKA as an equivalent of suicide attempts).

\section{Discussion}

Type 1 diabetes therapy requires full patient and/or caregiver involvement. Lack of at least minimal engagement makes treatment impossible and life threatening. Children need to gradually increase their independence in disease management [3]. Positive relationships with caregivers and good parental control are associated with better glycaemic control, whereas family conflicts, overprotection, and lack of control and commitment by caregivers are related with worse glycaemic results $[3,7]$. Decreased self-confidence, presence of psychiatric disorders, lower level of caregivers' education, lower family earnings, and higher alcohol consumption translate to worse glycaemic control and higher risk of DKA [2]. Conversely, support of loved ones, access to a psychologist, and education or understanding by a peer group relate to better glycaemic control through their impact on the patient's quality of life $[1,7]$.

Additionally, as many as one-third of children with T1D meet the criteria for at least one psychiatric diagnosis (eating disorders, anxiety and mood disorders - psychoactive substance abuse, personality disorders, depression, neurosis, and schizophrenia) during their lifetime $[4,5,8,9]$. The presence of mental disorders was found to be associated with higher haemoglobin $A_{1 c}$ and reduced quality of life, increased risk of acute diabetes complications, and hospitalization for other reasons including suicide attempts $[5,7]$. The current national and international recommendations emphasize the role of psychological care and quality of life $[6,7]$.

Recommendations of Diabetes Poland include care for patients in penitentiary institutions, but their fulfilment is difficult. The main problem is the lack of appropriate and precise legal regulations regarding self-care and allowing adequate care 
of minors with T1DM or other severe chronic diseases. If the patient is unable/unwilling to carry out self-management, then most likely he/she would not be properly supplied or controlled in terms of pharmacotherapy, as was the case in our patient. She neglected to control her glycaemia and insulin administration, so the PEYC police officers transported her to the hospital several times daily - each time she required an insulin injection. The officers rotated, so that each time the patient was accompanied by someone else, which completely paralyzed the flow of information (patient brought without the glucose meter and/ or pen provided a few hours earlier and without the planned meal). The PEYC director did not have the legal possibility and staff resources to provide adequate care.

In general, similar problems are encountered when treating patients who do not meet the "typical patient" criteria for various reasons. The example can be a female minor with T1DM and severe mental illness who is pregnant. For any of the departments (paediatric, diabetology, psychiatric, or obstetric) such a patient is not only an organizational and therapeutic challenge but also an administrative one. It often forces actions not sanctioned by law.

Our patient required psychiatric diagnosis because of repeated discontinuation of T1D treatment (repeated suicide attempts/decompensated psychiatric disorder/cognitive impairment that made it impossible to consciously assess the risk of stopping insulin treatment). It seems that based on the available

\section{References}

1. Skovlund SE, Peyrot M. The Diabetes Attitudes, Wishes, and Needs (DAWN) Program: A New Approach to Improving Outcomes of Diabetes Care. Diabetes Spectrum 2005; 18: 136-142.

2. Seear M, Amed S, Dionne J, Yang C, et. al. In support of point-ofcare social needs screening: The effects of five social determinants on the health of children with chronic diseases in British Columbia. Paediatr Child Health 2019; 24: 200-208. doi: 10.1093/pch/pxy090.

3. Wiebe DJ, Helgeson V, Berg CA. The social context of managing diabetes across the life span. Am Psychol 2016; 71: 526-538. doi: 10.1037/a0040355

4. Barnard-Kelly K, Naranjo D, Majidi S, et al. Suicide and self-inflicted injury in diabetes: a balancing act. J Diabetes Sci Technol 2020; 14 1010-1016. doi: 10.1177/1932296819891136.

5. SIldorf SM, Breinegaard N, Lindkvist EB, et al. Poor Metabolic Control in Children and Adolescents With Type 1 Diabetes and Psychiat- clinical data and the mother's consent to treatment there were no grounds for refusing hospitalization in a psychiatric ward.

Such unusual and demanding patients are encountered more and more often in daily practice. Comprehensive systemic solutions that would allow more flexibility in such cases are required. These regulations should apply not only to therapeutic procedures but also to the conduct of all other services: from social welfare to the police and penitentiary institutions.

\section{Conclusions}

In T1D the lack of insulin treatment is a direct threat to life. Mental disorders and/or social problems impair self-management and treatment or make it completely impossible. Such patients require care and support in every area of life. It also represents a significant challenge for the diabetes team, which needs support from consulting doctors of other specialties, social workers, or other services. The case of our patient shows that currently there are no relevant legal regulations that would allow quick and adequate care for such a child.

\section{Acknowledgements}

The authors would like to thank all parties involved in the patient's treatment and care as well as Karolina Piątek for proofreading. ric Comorbidity. Diabetes Care 2018; 41: 2289-2296. doi: 10.2337/ dc18-0609.

6. Diabetes Poland. 2020 Guidelines on the management of diabetic patients. A position of Diabetes Poland. Clin Diabetol 2020; 9 : 22-69.

7. Delamater AM, de Wit M, Mc Darby V, et al. ISPAD Clinical Practice Consensus Guidelines 2018: Psychological care of children and adolescents with type 1 diabetes. Pediatr Diabetes 2018; 19 (Suppl 27): 237-249. doi: 10.1111/pedi.12736

8. Majidi S, O'Donnell H, Stanek K, et al. Suicide Risk Assessment in Youth and Young Adults With Type 1 Diabetes. Diabetes Care 2020; 43: 343-348. doi: 10.2337/dc19-0831.

9. Almeida MC, Claudino DA, Grigolon RB, et al. Psychiatric disorders in adolescents with type 1 diabetes: a case-control study. Braz J Psychiatry 2018; 40: 284-289. doi: 10.1590/1516-4446-2017-2259. 